\title{
Penerapan Model TGT dengan Variasi LKPD Berbasis Kontekstual untuk Meningkatkan Minat Belajar Sosiologi Siswa Kelas XI IPS 1 SMAN 12 x11 Enam Lingkung Padang Pariaman
}

\author{
Diana Sri Mayani ${ }^{1}$, Junaidi Junaidi ${ }^{2}$ \\ ${ }^{1,2}$ Universitas Negeri Padang \\ Email: dianasrimayani@gmail.com, junaidiunp@fis.unp.ac.id
}

\begin{abstract}
Abstrak
Penelitian ini yang melatarbelakanginya adalah kurangnya minat belajar sosiologi peserta didik kelas XI IPS 1 SMAN 1 2x11 Enam Lingkung. Berdasarkan kasus tersebut solusi yang cocok untuk peningkatan minat belajar sosiologi peserta didik yaitu dengan menggunakan penerapan model yang cocok dengan peningkatan minat adalah menggunakan model pembelajaran TGT dengan variasi LKPD berbasis kontekstual. Tujuan penelitian ini adalah mendiskripsikan penerapan model pembelajaran TGT dengan variasi LKPD berbasis kontekstual untuk meningkatkan minat belajar sosiologi siswa kelas XI IPS 1 SMAN 1 2x11 Enam Lingkung. Penelitian ini merupakan penelitian tindakan kelas yang dilaksanakan dengan dua siklus. Setiap siklus dilakukan dengan dua kali petemuan. Setiap siklus terdiri dari 4 tahap kegiatan yaitu perencanaan, tindakan, pengamatan dan refleksi. Subjek penelitian adalah siswa kelas XI IPS 1 SMAN $12 \times 11$ Enam Lingkung dengan jumlah 30 orang. Pada kasus ini penulis menetapkan kategoti yang ingin di capai pada minat belajar sosiologi siswa pada skor presentase tinggi yaitu 76\%$100 \%$. Hasil yang didapat memperlihatkan bahwa penerapan model TGT dengan variasi LKPD berbasis kontekstual untuk meningkatkan minat belajar sosiologi siswa kelas XI IPS 1 SMAN 1 2x11 Enam Lingkung tahun ajaran 2019/2020 yang dibuktikan dengan adanya peningkatan persentase skor observasi minat belajar sosologi dari sebelum penerapan model pembelajaran TGT dengan variasi LKPD berbasis kontekstual skor presentasenya 29\%, setelah diterapkan model TGT pada siklus pertama skor nilai ratarata mengalami peningkatan dengan skor 39\% ke $68 \%$. Peningkatan tersebut terjadi pada siklus I menuju siklus II yaitu sebesar $12 \%$ sehingga didapat skor $80 \%$.
\end{abstract}

Kata Kunci: TGT dengan variasi LKPD berbasis kontekstual, Minat belajar, dan Siswa

\begin{abstract}
The background of this research is the lack of interest in learning sociology of students in class XI IPS 1 SMAN $12 x 11$ Enam Lingkung. Based on the case, a suitable solution for increasing students' sociological interest in learning is to use the application of a model that is suitable for increasing interest in using the TGT learning model with contextual variations based LKPD. The purpose of this study is to describe the application of the TGT learning model with contextual-based LKPD variations to increase the sociological interest in learning for students of class XI IPS 1 of SMAN $12 x 11$ Enam Lingkung. This research is a classroom action research conducted in two cycles. Each cycle is done with two meetings. Each cycle consists of 4 stages of activity namely planning, action, observation and reflection. The research subjects were students of class XI IPS 1 of SMAN $12 x 11$ Enam Lingkung with a total of 30 people. In this case the authors set the category to be achieved in the interest in learning sociology of students at a high percentage score of 76\%-100\%. The results obtained show that the application of the TGT model with contextual-based LKPD variations to increase sociology learning interest in class XI IPS 1 students of SMAN $12 x 11$ Six Circle 2019/2020 academic year as evidenced by an increase in the percentage of observation scores socology interest in learning from before the implementation of the TGT learning model with a contextual variation of LKPD based on the percentage score of $29 \%$, after applying the TGT model in the first cycle the average score increased by $39 \%$ to $68 \%$. The increase occurred in the first cycle to the second cycle which was $12 \%$ so that a score of $80 \%$ was obtained.
\end{abstract}

Keywords: TGT with contextual-based LKPD variations, interest in learning, and students

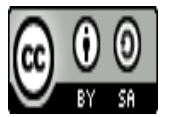


Diana Sri Mayani, Junaidi

Penerapan Model Pembelajaran TGT Dengan Variasi LKPD Berbasis Kontekstual

Untuk Meningkatkan Minat Belajar Sosiologi Siswa

\section{Pendahuluan}

Kelas XI IPS 1 SMAN 12 x11 Enam Lingkung Padang Pariaman

Minat merupakan rasa suka dan rasa ketertarikan terhadap suatu hal atau kegiatan, tanpa ada yang menyuruh (Slameto, 2010). Adanya minat dalam diri seseorang akan melahirkan perhatian untuk melakukan suatu aktivitas dengan tekun dalam jangka waktu yang lama, lebih berkonsentrasi, mudah untuk mengingat, dan tidak mudah bosan dengan apa yang dipelajari. Minat pada dasarnya adalah penerimaan akan sesuatu hubungan diri sendiri dengan sesuatu di luar diri sendiri. Semakin dekat dan kuat hubungan tersebut, maka minat akan semakin dekat (Mardiah, 2013).

Menurut Syaiful Bahri Djamarah (Haris, 2006) mengatakan minat merupakan kecenderungan terhadap suatu aktivitas dan meninggalkan daya ingat yang kuat oleh peminatnya atas aktivitas yang dilakukan. Aktivitas tersebut akan diulangi karena hal yang diisenangi untuk dilakukan seperti suatu hobi. Agus Sujanto (2004 : 92) berpendapat bahwa minat merupakan suatu yang jadi pusat perhatian seseorang yang meminatinya(Haris, 2006). Minat belajar adalah rasa suka atau ketertarikan terhadap pelajaran tertentu tanpa ada yang menyuruh. Apabila seseorang memiliki minat terhadap sesuatu maka dapat dilihat dari bagaimana dia memusatkan perhatiannya tersebut pada sesuatu yang sedang dia lakukan. Menurut (Haris, 2006) ciri-ciri siswa yang memiliki minat belajar dapal dilihat dari sikap dan bagaimana dia menjalani aktivitas belajar, seseorang yang berminat akan senang dalam melakukan aktivitas yang diminatinya tesebut. Aktivitas tersebut dianggap sebagai hobi yang akan disenangi setiap menjalaninya.

Dalam proses pembelajaran di kelas X1 IPS 1 SMAN 1 2X11 Enam Lingkung siswa hanya menggunakan satu sumber belajar berupa buku cetak sosiologi yang dipinjam dari perpustakaan sekolah. Pada proses pembelajaran siswa diminta untuk meringkas materi serta mengerjakan soal-soal dengan menggunakan sumber dari buku cetak tersebut. Setelah siswa meringkas materi yang dipelajari, guru mempresentasikan dengan metode ceramah materi tersebut. Pada saat guru menjelaskan siswa kurang bersemangat mengikuti pembelajaran dan melakukan kegiatan seperti mengobrol dengan teman sebangku, bermain handphone, serta keluar masuk kelas dengan berbagai alasan. Hanya siswa dengan peringkat teratas yang mengikuti pembelajaran dengan tenang, hal ini akan berdampak pada siswa dalam penguasaan materi maupun dalam segi peminatan dalam pembelajaran sosiologi. Pembelajaran dengan metode cermah berkelanjutan mengakibatkan ketidaktertarikan siswa untuk mengikuti proses pembelajaran didukung dengan sumber belajar yang hanya menggunakan buku cetak. Minat menjadi sumber motivasi yang kuat untuk belajar dan menjadi penyebab partisipasi dan keaktifan siswa dalam kegiatan pembelajaran karena itu dalam belajar harus diperlukan minat dari siswanya.

Minat belajar dapat diukur melalui 4 indikator sebagaimana yang disebutkan oleh (Slameto, 2010) yaitu ketertarikan untuk belajar, perhatian dalam belajar, motivasi belajar dan pengetahuan. Untuk mengetahui berminat atau tidaknya siswa terhadap mata pelajaran dapat dilihat dari empat indikator di atas. Ketertarikan pada pembelajaran dapat diartikan ketika seseorang yang berminat pada sesuatu kegiatan pembelajaran maka seseorang akan memiliki perasaan ketertarikan terhadap pembelajaran ditunjukkan dengan rajin belajar dan rasa ingin tahunya terhadap pelajaran tersebut. Perhatian dalam belajar diartikan dimana siswa dapat fokus terhadap apa yang dipelajarinya. Motivasi belajar dapat dilihat dari usaha atau dorongan yang dilakukan secara sadar untuk melakukan tindakan belajar dan mewujudkan perilaku yang terarah demi mencapai tujuan pembelajaran. Selanjutnya apabila seseorang tertarik terhadap suatu pembelajaran maka ia akan memiliki pengetahuan yang lebih luas dan mengetahui makna suatu pembelajaran. Kemudian Untuk mengetahui kategori minat belajar siswa maka menggunakan pedoman menurut Suharsimi Arikunto sebagai berikut: 
Tabel 1. Kategori Minat Belajar Siswa

Sumber: (Arikunto, 2013)

\begin{tabular}{cc}
\hline Persentase skor minat (\%) & Kriteria \\
\hline $76-100$ & Tinggi \\
\hline $56-76$ & Sedang \\
\hline $0-56$ & Rendah \\
\hline
\end{tabular}

Tabel 2. Tingkat Minat Belajar Siswa Kelas X IPS 1 SMAN 1 2X11 Enam Lingkung Padang Pariaman

\begin{tabular}{clcc}
\hline No & \multicolumn{1}{c}{ Indikator Minat } & Jumlah siswa & $\mathbf{\%}$ \\
\hline 1 & Ketertarikan untuk belajar & 10 & 30 \\
\hline 2 & Perhatian dalam belajar & 10 & 30 \\
\hline 3 & Motivasi belajar & 10 & 30 \\
\hline 4 & Pengetahuan & 8 & 24 \\
\hline
\end{tabular}

Sumber: Diolah dari data hasil observasi Pra tindakan pada tanggal 28 Maret 2019

Berdasarkan tabel di atas dapat dilihat dari 33 siswa di kelas X IPS 1 hanya 30\% keterlibatan untuk belajar terhadap pelajaran sosiologi, 30\% perhatian dalam belajar, 30\% motivasi belajar, yang lebih rendah lagi pengetahuan dalam pembelajaran sosiologi hanya $24 \%$. Jika diukur menggunakan pedoman menurut Suharsimi Arikunto, maka minat belajar siswa kelas X IPS 1 termasuk kedalam kriteria rendah yang berkisaran dari 0-56\%.

Upaya untuk meningkatkankan minat belajar sosiologi peserta didik merupakan salah satu faktor yang sangat diperhatikan pada proses pembelajaran karena apabila siswa memiliki minat maka pembelajaran akan berjalan lebih optimal. Salah satu yang perlu diperhatikan dalam dunia pendidikan adalah proses pembelajaran yang dikelola oleh guru mata pelajaran adalah siswa dapat berinternalisasi dengan banyak hal, sehingga proses pembelajaran tersebut memberikan sumbangan banyak dalam pementukan karakter seseorang(Fernandes, Vidya Putra, \& Muspita, 2019). Proses pendidikan terlaksana karena adanya pendidik(Fadilatur Rahmi, Junaidi, 2019). Guru merupakan profesi yang paling penting dan berpengaruh di sekolah (Satuan Pendidikan). Guru sebagai ujung tombak untuk menyalurkan ilmu pengetahuan kepada muridnya, maka guru dituntut tidak hanya memberikan pelajaran saja melainkan juga dapat dengan seksama membuat pembelajaran menjadi berkualitas, yaitu menarik, menantang, dan menyenangkan(Pujiastuti, n.d.). Guru diharuskan untuk dapat melakukan usaha-usaha dalam meningkatkan minat belajar siswa dalam proses pembelajaran, seperti melakukan pemvariasian dan inovasi dalam pembelajaran agar siswa tidak merasa bosan dan jenuh untuk belajar. Untuk meningkatkan hasil belajar peserta didik, para tenaga pendidik dapat menggunakan berbagai model pembelajaran yang tentunya sangat bervariasi dan tidak membosankan yang mana salah satunya adalah model pembelajaran cooperative learning tipe teams games tournament (tgt)(Arwidya, 2016).

Dalam model pembelajaran TGT siswa memainkan game dengan anggota lainnya untuk mencapai skor tinggi. Penyusunan permain bisa berupa kuis maupun pertanyaan yang terhubung dengan materi, seperti teka-teki. Tim dengan skor tertinggi akan mendapatkan reward berupa penghargaan atau sertifikat. Skor anggota tim dapat mempengaruhi 20 persen skor kelompok. (Robert E. Slavin, 2010). Model Kooperatif Teams Games Tournament, ini mempunyai kelebihan dan kekurangan. Menurut (Nugroho, Yusuf \& Setyawan, 2014) kelebihan dan kekurangan TGT adalah: 
a. Kelebihan: Lebih meningkatkan pencurahan waktu pada tugas, mengedepankan penerimaan pada perbedaan individu, dapat menguasai materi secara mendalam dengan waktu singkat, terdapat keaktifan siswa dalam proses pembelajaran, mendidik siswa agar dapat bersosialisasi dengan baik, motivasi belajar lebih tinggi, hasil belajar baik, meningkatkan kebaikan budi, kepekaan dan toleransi

\section{b. Kelemahan TGT}

a) Bagi guru: Sulitnya pengelompokan siswa yang mempunyai kemammpuan heterogen dari segi akademik, tetapi bisa diatasi dengan guru bertindak sebagai pemegang kendali, teliti dalam pembagian kelompok. Pada diskusi kelompok akan memakan waktu lebih banyak dari waktu yang ditentukan, tetapi bisa diatasi apabila pendidik dapat menguasai kelas

b) Bagi siswa: Masih adanya siswa yang berkemampuan tinggi scara akademis untuk mentransfer ilmunya pada teman sebayanya, untuk mengatasi guru memiliki tugas untuk membimbing siswa dengan baik agar mampu menularkan ilmunya.

Sedangkan LKPD juga dapat didefenisikan sebagai lembar kerja cetak berupa lembarlembar kertas yang berisi materi, ringkasan dan petunjuk-petunjuk pelaksanaan tugas yang harus dikerjakan oleh siswa, yang mengacu pada kompetensi dasar yang harus dicapai (Prastowo, 2012). Keunggulan model pembelajaran TGT adalah adanya turnamen akademik pada proses pembelajaran. Dimana setiap anggota kelompok mewakili kelompoknya untuk melakukan turnamen (Yulianto, Sumardi, \& Berman, 2016)

\section{Metode Penelitian}

Jenis penelitian ini adalah Penelitian Tindakan Kelas (PTK). Istilah dalam bahasa Inggris adalah Classroom Action Research (CAR), yaitu sebuah kegiatan penelitian yang dilakukan di kelas (Syaiful Bahri, 2011). Penelitian tindakan kelas merupakan suatu pencermatan terhadap kegiatan belajar berupa suatu tindakan, yang sengaja dimunculkan dan terjadi dalam sebuah kelas secara bersamaan (Suhardjono \& Supardi, 2015).

Teori yang dipakai peneliti adalah teori behavoristik. Pendekatan behavioristik merupakan orientasi teoretis yang didasarkan pada premis bahwa psikologi ilmiah harus berdasarkan studi tingkah laku yang teramati (observable behavior). Behaviorisme adalah teori perkembangan perilaku, yang dapat diukur, diamati dan dihasilkan oleh respon pelajar terhadap rangsangan. Tanggapan terhadap rangsangan dapat diperkuat dengan umpan balik positif atau negatif terhadap perilaku kondisi yang diinginkan (Arya Utama, 2010). Batasan keberhasilan minat belajar sosiologi siswa dilihat dengan membandingkan peningkatkan minat siswa sosiologi kasus siklus I dan siklus II. Untuk menentukan persentase skor pada indikator minat belajar sosiologi siswa digunakan rating clases menurut (Arikunto, 2013) dengan rumus $P=\frac{\mathrm{F}}{\mathrm{N}} \times 100 \%$. Target minat belajar yang diharapkan pada penelitian ini adalah kategori tinggi yakni pada interval 76\%-100\%. Berdasarkan kriteria tersebut, maka indikator keberhasilan minat belajar siswa dalam penelitian ini masuk dalam kategori tinggi dengan jumlah siswa yang berminat 23 dari 30 siswa.

\section{Hasil Penelitian}

Pada pelaksanaan penelitian tindakan kelas ini peneliti menggunakan dua siklus, setiap siklus terdapat dua pertemuan. Sebelum melakukan tindakan pada siklus I, peneliti melakukan pra tindakan terlebih dahulu. Peneliti mengamati proses pembelajaran siswa pada materi rancangan penelitian sosial. Pada setiap siklus terdiri dari 4 tahapan kegiatan, yang mana adalah perencanaan, pelaksanaan, pengamatan dan refleksi(Sanjaya, 2009). Di bawah ini adalah presentase dari tahap pra tindakan, siklus I dan siklus II 
Tabel 3. Presentase Minat Belajar Siswa Kelas X IPS 1 Mata pelajaran Sosiologi Tahap Pra Tindakan

\begin{tabular}{llcc}
\hline No & \multicolumn{1}{|c}{ Indikator minat } & $\begin{array}{c}\text { Jlh } \\
\mathbf{N}=33\end{array}$ & $\begin{array}{c}\text { Persentase } \\
\boldsymbol{P}=\frac{\boldsymbol{F}}{\boldsymbol{N}}\end{array}$ \\
& & & $30 \%$ \\
\hline 1. & Ketertarikan untuk belajar & 10 & $30 \%$ \\
\hline 2. & Perhatian dalam belajar & 10 & $30 \%$ \\
\hline 3. & Motivasi belajar & 10 & $24 \%$ \\
\hline 4. & Pengetahuan & 8 & $29 \%$ \\
\hline & Rerata & & \\
\hline
\end{tabular}

Sumber: Hasil pengamatan pada tanggal 28 Maret 2019

Ketika observasi pra tindakan peneliti mengamati bahwa model pembelajaran yang digunakan oleh guru adalah model ceramah yang berkelanjutan mengakibatkan kurangnya minat belajar sosiologi, siswa hanya sibuk dengan kegiatannya masing-masing seperti mengobrol dengan teman sekelas, keluar masuk kelas, tidur di dalam kelas bahkan ada yang menggambar dan mencoret-coret kertas. Berdasarkan tabel pra tindakan dapat dilihat bahwa minat belajar siswa pada mata pelajaran sosiologi tergolong rendah pada kelas X IPS 1 SMAN 1 2X11 Enam Lingkung. Hal ini dapat dibuktikan dengan minat siswa pada indikator ketertarikan untuk belajar sebesar $30 \%$, perhatian dalam belajar 30\%, motivasi belajar $30 \%$, dan pengetahuan $24 \%$. Jika dirata-ratakan terdapat hasil $29 \%$ dari keempat indikator minat belajar yang termasuk ke dalam kategori rendah yaitu 0\%-56\% sedangkan kategori capaian peneliti adalah minat belajar siswa termasuk ke dalam kategori tinggi yaitu 76\%-100\%.

\section{Siklus I}

Pada pertemuan pertama siswa mengikuti pembelajaran dengan baik dan bersemangat tetapi masih ada sebagian siswa yang masih belum termotivasi dan ikut aktif dalam pembelajaran karena baru pertama kali mengenal dan merasakan model pembelajaran TGT dengan variasi LKPD berbasis kontekstual, tetapi peneliti berusaha melanjutkan pada pertemuan kedua. Dari dua pertemuan pada siklus 1 peneliti menemukan presentase minat belajar sosiologi siswa dapat dilihat pada tabel di bawah :

Tabel 4. Tingkat Minat Belajar Siswa Kelas XI IPS 1 Pada Mata Pelajaran Sosiologi Siklus I

\begin{tabular}{llcc}
\hline No & \multicolumn{1}{|c}{ Indikator minat } & $\begin{array}{c}\text { Jumlah } \\
\mathbf{N = 3 0}\end{array}$ & $\begin{array}{c}\text { Persentase } \\
\boldsymbol{P}=\frac{\boldsymbol{F}}{\boldsymbol{N}}\end{array}$ \\
\hline 1. & Ketertarikan untuk belajar & 20 & $67 \%$ \\
\hline 2. & Perhatian dalam belajar & 20 & $67 \%$ \\
\hline 3. & Motivasi belajar & 22 & $73 \%$ \\
\hline 4 & Pengetahuan & 19 & $63 \%$ \\
\hline & Rata-rata & & $68 \%$ \\
\hline
\end{tabular}

Sumber: Diolah dari pengamatan siklus II tangal 25 dan27 Juli 2019

Berdasarkan tabel di atas dapat dijelaskan tingkat persentase minat belajar siswa kelas XI IPS 1 pada pelajaran sosiologi saat siklus pertama yaitu sebagai berikut: pada indikator ketertarikan untuk belajar siswa XI IPS 1 adalah sebanyak 20 orang dari 30 orang jumlah siswa, jika dipersentasekan sebesar $67 \%$. Pada indikator perhatian dalam belajar terdapat 20 siswa, jika

Jurnal Sikola: Jurnal Kajian Pendidikan dan Pembelajaran Vol. 1, No. 1, Th. 2019 
Diana Sri Mayani, Junaidi Penerapan Model Pembelajaran TGT Dengan Variasi LKPD Berbasis Kontekstual Untuk Meningkatkan Minat Belajar Sosiologi Siswa Kelas XI IPS 1 SMAN 12 2x11 Enam Lingkung Padang Pariaman dipersentasekan sebesar $67 \%$. Pada indikator motivasi belajar terdapat 22 siswa jika dipersentasekan sebesar 73\%. Kemudian pada indikator pengetahuan terdapat 19 siswa jika dipersentasekan sebesar $63 \%$. Jika dirata-ratakan pesentase tingkat minat belajar siswa kelas XI IPS 1 selama siklus pertama adalah sebesar $68 \%$.

\section{Siklus II}

Pada siklus II dengan dua kali pertemuan terdapat peningkatan minat belajar sosiologi siswa jika dibanding dengan siklus 1 , presentase kenaikan dapat dilihat dari tabel persentase dibawah ini:

\section{Tabel 5. Tingkat Minat Belajar Sosiologi Kelas XI IPS 1 Siklus II Pelajaran Sosiologi}

\begin{tabular}{llcc}
\hline No & \multicolumn{1}{c}{ Indikator Minat } & $\begin{array}{c}\text { Jumlah } \\
\mathbf{N = 3 0}\end{array}$ & $\begin{array}{c}\text { Persentase } \\
\boldsymbol{P}=\frac{\boldsymbol{F}}{\boldsymbol{N}}\end{array}$ \\
\hline 1. & Ketertarikan belajar & 26 & $87 \%$ \\
\hline 2. & Perhatian dalam belajar & 24 & $80 \%$ \\
\hline 3. & Motivasi belajar & 24 & $80 \%$ \\
\hline 4 & Pengetahuan & 22 & $73 \%$ \\
\hline & Rata-rata & & $80 \%$ \\
\hline
\end{tabular}

Sumber: Diolah pada pengamatan selama siklus III pada tanggal 29-31 Juli 2019

Berdasarkan tabel di atas dapat dijelaskan tingkat persentase minat belajar siswa kelas XI IPS 1 selama siklus kedua yaitu sebagai berikut: pada indikator ketertarikan untuk belajar siswa adalah sebanyak 26 orang dari 30 orang jumlah siswa, jika dipersentasekan sebesar $87 \%$. Pada indikator perhatian dalam belajar terdapat 24 siswa, jika dipersentasekan sebesar $80 \%$. Pada indikator motivasi belajar terdapat 24 siswa jika dipersentasekan sebesar $80 \%$. Kemudian pada indikator pengetahuan terdapat 22 siswa jika dipersentasekan sebesar 73\%. Jika dirata-ratakan pesentase tingkat minat belajar sosiologi siswa kelas XI IPS 1 selama siklus ketiga adalah sebesar 80\%. Jika dikategorikan menurut pendapat (Arikunto, 2006) minat belajar sosiologi siswa kelas XI IPS 1 pada siklus II termasuk ke dalam kategori tinggi yaitu persentase $76 \%$ ke atas, karena hasilnya sesuai capaian peneliti, maka peneliti sudahi penelitian ini.

\section{Pembahasan}

Dilihat dari analisis penamatan pada penelitian yang dijalankan pada kelas XI IPS 1 SMAN 12 2x11 Enam Lingkung, minat belajar sosiologi siswa pada dari siklus I dan siklus II mengalami peningkatan secara keseluruhan. Rata-rata peningkatan persentase minat belajar sosiologi siswa kelas XI IPS 1 SMAN 12 X11 Enam Lingkung yaitu siklus I dengan persentase $68 \%$ meningkat pada siklus II dengan persentase $80 \%$. Dibawah ini adalah tabel penaikan presentase pra tindakan, siklus I dan siklus II:

Tabel 6. Peningkatan Minat Belajar Sosiologi Kelas XI IPS 1 Pada Tahap Pra Tindakan, Siklus I, dan Siklus II.

\begin{tabular}{clccccc}
\hline No & $\begin{array}{c}\text { Indikator } \\
\text { Minat }\end{array}$ & $\begin{array}{c}\text { Persentase } \\
\text { Pra } \\
\text { Tindakan }\end{array}$ & $\begin{array}{c}\text { Persentase } \\
\text { pada Siklus I }\end{array}$ & $\begin{array}{c}\text { Peningkatan } \\
\text { Persentase } \\
\text { Pra Tindakan } \\
\text { ke Siklus I }\end{array}$ & $\begin{array}{c}\text { Persentase } \\
\text { Siklus II }\end{array}$ & $\begin{array}{c}\text { Peningkatan } \\
\text { Persentase } \\
\text { Siklus I ke } \\
\text { Siklus II }\end{array}$ \\
\hline 1 & $\begin{array}{l}\text { Ketertarikan } \\
\text { untuk belajar }\end{array}$ & $30 \%$ & $67 \%$ & $37 \%$ & $87 \%$ & $20 \%$ \\
\hline 2 & Perhatian & $30 \%$ & $67 \%$ & $37 \%$ & $80 \%$ & $13 \%$ \\
\hline
\end{tabular}

Jurnal Sikola: Jurnal Kajian Pendidikan dan Pembelajaran Vol. 1, No. 1, Th. 2019 
Diana Sri Mayani, Junaidi

Penerapan Model Pembelajaran TGT Dengan Variasi LKPD Berbasis Kontekstual Untuk Meningkatkan Minat Belajar Sosiologi Siswa Kelas XI IPS 1 SMAN $12 x 11$ Enam Lingkung Padang Pariaman

\begin{tabular}{|c|c|c|c|c|c|c|}
\hline \multicolumn{7}{|c|}{ dalam belajar } \\
\hline 3 & $\begin{array}{l}\text { Motivasi } \\
\text { Belajar }\end{array}$ & $30 \%$ & $73 \%$ & $43 \%$ & $80 \%$ & $7 \%$ \\
\hline 4 & Pengetahuan & $24 \%$ & $63 \%$ & $39 \%$ & $73 \%$ & $10 \%$ \\
\hline & Rata-rata & $29 \%$ & $68 \%$ & $39 \%$ & $80 \%$ & $12 \%$ \\
\hline
\end{tabular}

Sumber: Diolah dari data hasil pengamatan selama tahap pra tindakan, siklus I, dan siklus II

Pada siklus kedua ini peneliti melihat peningkatan persentase dari pra tindakan sampai pada siklus kedua pada semua indikator minat belajar sosiologi siswa. Peningkatan pada siklus pertama ke siklus kedua peningkatan indikator ketertarikan untuk belajar siswa meningkat 6 orang dari 20 siswa atau $67 \%$ menjadi 26 siswa atau $87 \%$ peningkatannya sebesar $20 \%$. Pada indikator perhatian dalam belajar persentase minat belajar sosiologi siswa juga meningkat dari 20 siswa atau $67 \%$ menjadi 24 siswa atau $80 \%$ peningkatanya sebesar $13 \%$. Pada indikator motivasi belajar meningkat yaitu dari 22 siswa atau $73 \%$ ke 24 siswa atau $80 \%$ presentase peningkatan sebesar 7\%. Pada indikator pengetahuan persentase minat belajar sosiologi siswa juga meningkat dari 19 siswa atau $63 \%$ menjadi 22 siswa atau $73 \%$ peningkatannya sebesar 10\%. Rata-rata dari siklus II adalah $80 \%$ meningkat $12 \%$ dari siklus I. Jika dikategorikan menurut pendapat Arikunto minat belajar sosiologi siswa di kelas XI IPS 1 pada siklus II tergolong ke dalam kategori tinggi yaitu persentase $76 \%-100 \%$.

Data di atas emperlihatkan bahwa pentingnya memberikan keyakinan kepada siswa jika mereka mampu memahami materi, mereka tidak perlu merasa cemas dengan pertanyaan dan jawaban yang mereka berikan serta mereka akan mampu mengembangkan kemampuan dan minatnya, dan hal ini berarti perkembangan intelektual siswa telah meningkat.(Sylvia, 2012)

\section{Kesimpulan}

Berdasarkan data yang diperoleh selama penelitian dapat disimpulkan bahwa model pembelajaran TGT dengan variasi LKPD berbasis kontekstual terdapat hasil peningkatan minat belajar sosiologi pada siswa kelas XI IPS 1 SMAN 1 2x11 Enam Lingkung. Berikut data peningkatan minat belajar sosiologi siswa kelas XI IPS 1 SMAN 1 2x11 Enam Lingkung menggunakan model pembelajaran TGT dengan variasi LKPD berbasis kontekstual:

1. Dilihat secara keseluruhan minat belajar sosiologi siswa mengalami peningkatan dari tahap pra tindakan dengan presentase $29 \%$ ke siklus I menjadi $68 \%$, peningkatann sebesar $39 \%$. Kemudian dari siklus I sebesar $68 \%$ ke siklus II juga mengalami peningkatan dengan nilai $80 \%$, peningkatannya adalah senilai $12 \%$.

2. Dari 4 indikator minat belajar sosiologi semuan mengalami peningkatan persentase, pada indikator ketertarikan untuk belajar tahap pra tindakan persentase yaitu $30 \%$, dan meningkat pada siklus I menjadi $67 \%$ kemudian meningkat lagi pada siklus II menjadi $87 \%$. Indikator perhatian dalam belajar pada tahap pra tindakan dengan persentase $30 \%$ meningkat pada siklus I menjadi $67 \%$ dan peningkatan pada siklus II menjadi $80 \%$. Kemudian pada indikator motivasi belajar tahap pra tindakan persentasenya sebesar $30 \%$ meningkat pada siklus I menjadi $73 \%$, kemudian meningkat lagi pada siklus II menjadi $80 \%$. Selanjutnya pada indikator pengetahuan saat tahap pra tindakan persentasenya adalah sebesar $24 \%$ meningkat pada siklus I menjadi $63 \%$ dan meningkat lagi pada siklus II menjadi $73 \%$, tiga persentase indikator minat pada siklus II tergolong kategori tinggi, kecuali pada indikator pengetahuan hanya $73 \%$ yang tergolong sedang yang bukan menjadi capaian peneliti menurut pendapat Arikunto, akan tetapi rata-rata minat belajar sosiologi telah tergorong kategori tinggi sehingga penelitian menyelesaikan penelitian sampai siklus II.

Jurnal Sikola: Jurnal Kajian Pendidikan dan Pembelajaran Vol. 1, No. 1, Th. 2019 
Diana Sri Mayani, Junaidi Penerapan Model Pembelajaran TGT Dengan Variasi LKPD Berbasis Kontekstual Untuk Meningkatkan Minat Belajar Sosiologi Siswa Kelas XI IPS 1 SMAN $12 x 11$ Enam Lingkung Padang Pariaman

3. Minat belajar sosiologi dapat meningkat menggunakan model pembelajaran TGT dengan variasi LKPD berbasis kontekstual karena dalam pembelajaran siswa sangat berperan aktif, guru bukan lagi pusat dalam proses pembelajaran. Siswa dapat berlomba-lomba mencari jawaban sehingga menimbulkan rasa ketertarikan dalam belajar, serta motivasi dalam proses pembelajaran. Penggunaan LKPD juga dapat mempermudah siswa dalam memahami konsep sosiologi dan mempermudah siswa dalam bagaimana penerapan pembelajaran sosiologi pada lingkungannya.

\section{Daftar Pustaka}

Arikunto. (2013). Prosedur Penelitian: Suatu Pendekatan Praktik. Jakarta: Rineka Cipta.

Arikunto, S. (2006). Prosedur Penelitian: Suatu Pendekatan Praktik. Jakarta: Rineka Cipta.

Arwidya, S. (2016). PENERAPAN MODEL PEMBELAJARAN KOOPERATIF TIPE TGT (TEAMS GAMES TOURNAMET) UNTUK MENINGKATKAN KEAKTIFAN DAN HASIL BELAJAR SOSIOLOGI KELAS XI IPS 3 SMA N 3 BOYOLALI TAHUN PELAJARAN 2015/2016 Shinta.

Arya Utama. (2010). Pengertian Perilaku Agresif.

Fadilatur Rahmi, Junaidi, R. F. (2019). Human Capital Mahasiswa Universitas Terbuka Sebagai Guru Honorer (Studi Kasus: Guru Honorer Di Sd Negeri 01 Pangkalan, Sd Negeri 10 Pangkalan Dan Mis Pangkalan, Kecamatan Pangkalan Koto Baru, Kabupaten Lima Puluh Kota). 2(2), 66-74.

Fernandes, R., Vidya Putra, E., \& Muspita, R. (2019). Optimalisasi Institusi Pendidikan Sebagai Upaya Pengendalian Hoax. ABDI: Jurnal Pengabdian Dan Pemberdayaan Masyarakat, 1(1), 16-20. https://doi.org/10.24036/abdi/vol1-iss1/2

Haris, A. (2006). Psikologi Dalam Pendidikan. Bandung: CV Alvabeta.

Mardiah, A. (2013). Perbedaan Minat Belajar Berdasarkan Jenis Sekolah di Kalangan Mahasiswa Sosiologi Fakultaas Ilmu Sosial Universitas Negeri Padang. 269-276.

Nugroho, Yusuf, S., \& Setyawan. (2014). Universitas Muhammadiyah Surakarta. Klasifikasi Masa Studi Mahasiswa Fakultas Komunikasi Dan Informatika Universitas Muhammadiyah Surakarta Menggunakan Algoritma C4.5, VI(1), 84-91.

Prastowo, A. (2012). Panduan Kreatif Membuat Bahan Ajar Inovatif. Yogyakarta: Diva Press.

Pujiastuti, P. (n.d.). Pembelajaran ipa sd melalui model kooperatif.

Robert E. Slavin. (2010). Cooperative Learning Teori, Riset dan Praktik. Bandung: Nusa Media.

Sanjaya, W. (2009). Penelitian Tindakan Kelas. Jakarta: Pranemedia Group.

Slameto. (2010). Belajar dan Faktor-faktor yang Mempengaruhinya. Jakarta: Rineka Cipta.

Suhardjono, A. S., \& Supardi. (2015). Penddidikan Tindakan Kelas. Jakarta: PT Bumi Aksara.

Syaiful Bahri, D. (2011). Psikologi Belajar. Jakarta: Rineka Cipta.

Sylvia, I. (2012). Jurnal Diakronika, Vol XII, No 2 Th 2012. Diakronika, XII(02), 163-182. https://doi.org/10.31227/osf.io/76cym

Yulianto, W. D., Sumardi, K., \& Berman, E. T. (2016). Model Pembelajaran Teams Games Tournament Untuk Meningkatkan Hasil Belajar Siswa Smk. Journal of Mechanical Engineering Education, 1(2), 323. https://doi.org/10.17509/jmee.v1i2.3820 